\title{
Sensitivity of three tomato (Lycopersicon esculentum) cultivars - Akoma, Pectomech and power- to chilling injury
}

\author{
Kumah, P, Olympio, N. S., Tayviah, C. S. \\ Department of Horticulture, Faculty of Agriculture, College of Agriculture and Natural \\ Resources, Kwame Nkrumah University of Science and Technology, Kumasi \\ Corresponding author: patrickumah@yahoo.co.uk
}

\begin{abstract}
Sensitivity to chilling injury of three local tomato cultivars (Akoma, Pectomech and Power) at full ripe stage was investigated. Full ripe fruits of the three cultivars were stored for seven, fourteen and twenty-one days at $10^{\circ} \mathrm{C}$ and then transferred to ambient condition $\left(20.49^{\circ} \mathrm{C}\right.$ and $54.05 \%$ relative humidity) storage for seven days during which the various treatments were observed for signs of chilling injury. There was a significant difference $(p<0.05)$ in the sensitivity of the three cultivars to chilling injury. For fruits stored at $10^{\circ} \mathrm{C}$ for seven days, Akoma was least affected by chilling. Pectomech was the least tolerant to chilling after seven days of storage at the low temperature but there was no significant difference $(p>0.05)$ between its sensitivity to chilling and that of Power. There was, however, no significant difference $(p>0.05)$ in the overall quality of all the three cultivars stored for seven days under the low temperature. Akoma fruits had the best quality after fourteen days of chilling and maintained their quality for four days under ambient storage conditions. Power was the most sensitive to chilling injury after fourteen days and had the lowest quality. Pectomech was of better quality than Power after fourteen days of storage but the difference was not significant $(p>0.05)$. After twenty-one days of storage at low temperature, Power was the most susceptible to chilling and was of the lowest quality. Power and Pectomech lasted for one day under ambient conditions after twenty-one days of exposure to the low temperature. Although, Pectomech scored a better quality than Power, there was no significant difference $(p>0.05)$ in their susceptibility to chilling. Akoma was the least susceptible to chilling after twenty-one days and maintained its quality for a period of three days under ambient conditions. The most tolerant tomato cultivar to chilling injury was Akoma and the least tolerant cultivar was Power.
\end{abstract}

\section{INTRODUCTION}

Tomato (Lycopersicon esculentum. Mill) is a herbaceous, usually sprawling plant in the Solanaceae or nightshade family (Peralta and Spooner, 2001). Tomato is a popular vegetable with a high per capita consumption in Ghana as it is used in almost all Ghanaian homes (Asare-Bediako et al., 2007). It contributes significantly to the economic growth of Ghana and a source of foreign exchange (Franzio, 1996). In 2003, 4,368 metric tonnes of tomatoes were exported, accruing a foreign exchange of $\$ 427,000$ to the country (FAO, 2005).

Postharvest losses in tomato fruits could occur as a result of chilling injury, insect damage, mechanical damage and stress during production, improper harvest sanitation, poor cooling and ventilation, and environment control (Beecher, 1998). Tomato is very perishable because of its high moisture content and this makes it encounter high postharvest losses. Tomato fruits are thus stored in cold environment under refrigeration with temperatures ranging between $0^{\circ} \mathrm{C}$ and $15^{\circ} \mathrm{C}$. According to Levitt (1980), irreversible damage may be caused to tropical and sub-tropical species which are stored between $0^{\circ} \mathrm{C}$ $15^{\circ} \mathrm{C}$. This irreversible damage caused by the exposure to such cold storage temperature is commonly referred to as chilling injury.

Despite the economic and nutritional importance of tomato, very little research has been done to identify the optimum environmental conditions for extending postharvest life of tomatoes. Millennium Development Authority (MiDA) will soon introduce several technologies into the postharvest systems of Ghana including the building of cold pack houses and storage (MiDA, 2008). The objectives of this study therefore, were to determine the sensitivity of three tomato cultivars (Power, Akoma and Pectomech) to 
chilling, and effect of the storage temperature and chilling on quality and postharvest life of the three MATERIALS AND METHODS

The experiment was conducted at the laboratory of the Department of Horticulture, Kwame Nkrumah University of Science and Technology, Kumasi, Ghana. The experiment lasted for a period of four weeks. The weight, pulp temperature, firmness, total soluble solid (TSS) and $\mathrm{pH}$ were measured initially and after the fruits were exposed to low temperatures. The weight of the fruits was measured with a digital scale (AOAC, 1992; Dadzie and Orchard, 1997). The pulp temperature was measured with a digital temperature probe (Kitinoja and Husein, 2005). The firmness of the fruit was measured with an Effigi penetrometer (Kitinoja and Husein, 2005). The total soluble solid of the fruit was measured with a hand refractometer (Kitinoja and Husein, 2005). tomato cultivars (Power, Akoma and Pectomech).

The $\mathrm{pH}$ of the tomato fruit was measured with a $\mathrm{pH}$ test strips (Kitinoja and Husein, 2005).

The tomato fruits were exposed to $10^{\circ} \mathrm{C}$ (Cheng and Shewfelt, 1987) for seven, fourteen and twenty-one days (Mohammed and Brathwaite, 2000). The refrigerator for chilling was preset to a temperature of $10^{\circ} \mathrm{C}$ (Cheng and Shewfelt, 1987). The relative humidity in the refrigerator was $85 \%$. All the fruits were set at the same temperature but the duration of exposure to chilling varied. The cultivars were Akoma $(A)$, Pectomech $(P)$ and Rendo $(R)$ and the duration of chilling also were seven (7), fourteen (14) and twenty one (14) days. The treatment combinations were as follows (Table 1);

Table 1: Treatment combinations of experiment

\begin{tabular}{|c|c|c|c|}
\hline \multicolumn{1}{|c|}{ CULTIVARS } & AKOMA (A) & PECTO (P) & POWER (PO) \\
\cline { 1 - 3 } REPLICATION & $\mathrm{A}_{7}$ & $\mathrm{P}_{7}$ & $\mathrm{PO}_{7}$ \\
\hline 1 & $\mathrm{~A}_{7}$ & $\mathrm{P}_{7}$ & $\mathrm{PO}_{7}$ \\
\hline 3 & $\mathrm{~A}_{7}$ & $\mathrm{P}_{7}$ & $\mathrm{PO}_{14}$ \\
\hline 1 & $\mathrm{~A}_{14}$ & $\mathrm{P}_{14}$ & $\mathrm{PO}_{14}$ \\
\hline 2 & $\mathrm{~A}_{14}$ & $\mathrm{P}_{14}$ & \\
\hline
\end{tabular}

The overall quality, was based on the general

Chilling injury was measured by scoring for pitting and decay, resistance to chilling injury, overall quality and brown discolouration of tissues (Mohammed and Brathwaite, 2000). The scoring for pitting and decay was done using an 8-point hedonic scale (Cabrera and Saltveit, 1992). The scoring system was $0=$ no pitting or decay $(0 \%$ of the fruit surface was pitted or decayed, $2=$ slight $(1 \%$ to $5 \%), 4=$ moderate $(6 \%$ to $15 \%), 6=$ severe $(16 \%$ to $75 \%)$, and $8=$ very severe $(>75 \%)$. Brown discolouration on fruit skin indicative of chilling injury was scored on a 5-point hedonic scale where $0=$ no discolouration, $1=0-10 \%$ discolouration, $2=11-20 \%$ discolouration, $3=21$ $40 \%$ discolouration, $4=41-60 \%$ discolouration and 5 $=>60 \%$ discolouration (Cabrera and Saltveit, 1992). Resistance of the fruit to chilling injury was ranked for each cultivar on a scale of $1-10$ with $1=$ most susceptible and $10=$ most resistant (Cabrera and Saltveit, 1992). The scoring was done after a through visual examination was done to look out for the severity of the various symptoms of chilling injury. appearance of the fruit and it acceptability by the consumer. It was measured subjectively on an 8point hedonic scale where $0=$ poor (extremely defective), 2 = fair (defective), 4 = good (moderately defective), 6 = very good (slightly defective), $8=$ excellent (not defective) (Cabrera and Saltveit, 1992).

The data collected was analysed using GenStat Release 7.22DE. LSD at $5 \%$ was used to show significance level between treatments.

\section{RESULTS AND DISCUSSION}

Cumulative Weight Loss: Weight loss is directly attributed to water loss (Farooqi et al,.1998). Hudson (1990) stated that the weight of tomato fruits varied with cultivars. The weight of the tomato fruits stored for seven days was significantly different $(p<0.05)$ between Akoma and Pectomech and Pectomech and Power. The fruits that were stored for fourteen days had no significant difference $(p \geq 0.05)$ in their weight changes. Also, there was significant difference in the cumulative weight loss of Akoma and Pectomech, and Akoma and Power ( $p \leq 0.05)$. These differences 
were due to differences in cultivar (Abou-Aziz et al., 1976). The weight loss in the fruits chilled for fourteen day was higher compared to that of the weight loss after seven days. It can also be observed in the weight loss of the fruits chilled for twenty one day was greater than those stored for seven and fourteen days. The difference was due to the fact that the fruits were stored for different storage duration (Hobson, 1981). This is similar to the research carried out by Znidarcic and Pozrl in 2006. In their research they recorded that tomato stored at longer period had greater weight loss.

Table 2: Average cummulative weight loss (\%)

\begin{tabular}{|l|l|l|l|}
\hline \begin{tabular}{l|l|l|} 
CHILLING \\
PERIOD
\end{tabular} & 7 & 14 & 21 \\
\cline { 1 - 3 } VARIETY & & & \\
\hline AKOMA & $6.54 \mathrm{a}$ & $12.23 \mathrm{a}$ & $20.84 \mathrm{a}$ \\
\hline PECTOMECH & $14.72 \mathrm{~b}$ & $18.08 \mathrm{a}$ & $33.98 \mathrm{~b}$ \\
\hline POWER & $8.71 \mathrm{a}$ & $17.53 \mathrm{a}$ & $37.37 \mathrm{~b}$ \\
\hline
\end{tabular}

Fruits stored for twenty-one days under the low temperature recorded the highest percentage weight loss. There was no significant difference $(p \geq 0.05)$ between the percentage weight losses of all the three cultivars stored for fourteen days and kept under ambient conditions for seven days.

Pulp Temperature: Cold temperature converts the sugars to starch and also causes the firm texture of tomato to turn pulpy (Adegoroye et al., 1989; McDonald et al., 1999). Temperature of fruits and vegetables affect their rate of ripening, respiration, and deterioration rate. This, therefore, means that the pulp temperature has a direct impact on the firmness, the brix and the $\mathrm{pH}$ of the tomato fruits (McDonald et al. 1999).

There was a significant difference $(p<0.05)$ between the pulp temperature of Akoma and Pectomech, and Akoma and Power. This difference could be attributed to the difference in cultivar (Abou-Aziz et al., 1976). It could also be attributed the fact that the biochemical reactions within Power and Pectomech were drastically slowed down and hence, they approached senescence quickly (Socchets, 2000).

Each variety had slight variation in the pulp temperature between the various durations for which they were kept under the low temperature storage. This was because the rate of respiration was slowed down under the low temperatures and increased slight when the fruits were brought to ambient condition storage (Mohammed et al., 2005). The pulp temperature of Pectomech and Power was generally lower than that of Akoma stored under ambient conditions for seven day. This, therefore, means that Power and Pectomech approached senescence faster than Akoma.

Table 3: Average pulp temperature $\left({ }^{\circ} \mathrm{C}\right)$

\begin{tabular}{|l|l|l|l|}
\hline $\begin{array}{l}\text { CHILLING } \\
\text { PERIOD }\end{array}$ & 7 & 14 & 21 \\
\cline { 1 - 3 } VARIETY & & & \\
\hline AKOMA & $25.67 \mathbf{a}$ & $25.71 \mathbf{a}$ & $25.67 \mathbf{a}$ \\
\hline PECTOMECH & $24.93 \mathbf{b}$ & $24.97 \mathbf{b}$ & $24.99 \mathbf{b}$ \\
\hline POWER & $24.89 \mathbf{b}$ & $24.97 \mathbf{b}$ & $24.89 \mathbf{b}$ \\
\hline
\end{tabular}

Firmness: Firmness can also be attributed to the lipid bond structure of the skin tissue. Fruits susceptible to chilling injury have their lipid bonds broken such that the skin tissue become soft and easy to break (Thompson, 1999). This therefore means that after the exposure of tomato fruits to low temperatures, they showed susceptibility to chilling injury and hence, their loss in firmness.

Akoma stored for fourteen days was the firmest as compared with Akoma stored for seven and twentyone days. This was also firmer than Pectomech and Power stored for the same period of days. Pectomech exposed to twenty one days of low temperatures and stored at ambient conditions for seven day recorded the least firmness. There was no significant difference $(p \geq 0.05)$ between the firmness of fruits chilled seven days and stored under ambient conditions for seven days. However, there was a significant difference $(p<0.05)$ the firmness of Akoma and Pectomech, and Akoma and Power. This difference could be attributed to differences in cultivar ((Abou-Aziz et al., 1976) and the duration of storage (Hobson, 1981).From the experiment, it was observed that Akoma had a thicker skin tissue compared to Pectomech and Power. It is generally observed from the experiment that the firmness of the fruits dropped from day one till day seven. This result is similar to a study conducted by Mohamed et al., (1994), where they concluded that the longer the fruit stays on the shelf, the faster the rate of loss of firmness.

Table 4: Average fruit firmness $(\mathrm{kg})$

\begin{tabular}{|l|l|l|l|}
\cline { 1 - 2 } CHILLING PERIOD & 7 & 14 & 21 \\
\cline { 1 - 2 } VARIETY & & & \\
\hline AKOMA & $1.30 \mathrm{a}$ & $2.02 \mathrm{a}$ & $1.39 \mathrm{a}$ \\
\hline PECTOMECH & $1.09 \mathrm{a}$ & $0.96 \mathrm{~b}$ & $0.63 \mathrm{~b}$ \\
\hline POWER & $1.36 \mathrm{a}$ & $0.78 \mathrm{~b}$ & $0.66 \mathrm{~b}$ \\
\hline
\end{tabular}


Total soluble solids: The total soluble is a measure of mainly how much sucrose is in a plant sap. The measure of brix can used to determine sweetness of fruits and vegetables. From the results it can be seen that the total soluble of the tomato fruits increased slightly one or two days after they were taken to ambient conditions. This could be due to the fact that during chilling enzymatic activities was not total stopped but reduced so starch was still been converted to sugar. According Salunkha et al. (1974), the increment of soluble solids is caused by the biosynthesis processes or degradation of polysaccharides during maturity.

There were significant differences $(p<0.05)$ in the brix values of all the three cultivars stored under low temperature for seven days and fourteen days then exposed to ambient conditions for seven days. For fruits stored for twenty-one days under the low temperature and under ambient conditions for seven days, there was a significant difference $(p<0.05)$ between the brix value of Akoma and Pectomech, and Power and Pectomech. These differences were due to the difference in the rate of biochemical reactions (Salunkha et al., 1974), respiration (Socchets, 2000) and cultivar (Abou-Aziz et al., 1976)

The brix reading recorded ranged between low and average as the values between 2 to 4.5. This was done using both Reams chart and Neilsons Chart; the Brix reading of tomato according to Ream's chart is $4,6,8$ and 12 for poor, average, good and excellent tomato respectively (Harrill, 1998). The Brix of poor, average, good and excellent tomato fruits is 4, 6, 10 and 14 (Neilson's chart; Skow, 1998).

Also the readings fell in a range similar to that of the work done by Nkansah et al., (2003) where the concluded that the Brix reading of tomato cultivars in Ghana ranged from 3.5 - 5.6. The slight increment in the brix value just after chilling is also similar to the study conducted by Znidarcic and Pozrl (2006). In their study they found that the brix of tomato fruits store for twenty one days at $10^{\circ} \mathrm{C}$ increased slightly from 5.06 to 6.92 .

The brix of all the three cultivars before exposure to low temperature was between 3.97-4.00. This could be because the fruits were all taken from the same field and given the same field treatments. It was also observed that the brix reduce as the tomato experience chilling injury. Also, after the slight increment of the brix a day under ambient conditions, it dropped for all cultivars till the end of the experiment. This could be attributed to the fact that the necrosis reduces the amount of sugar in the tomato (Thompson, 1999). It can also be observed that the $\mathrm{pH}$ of the tomato increased as the brix dropped and hence, the reduction in acidity contributed some sourness to the tomato fruits. Will et al., (1981) showed, that amount of organic acid usually decrease during maturity, because they are substrate of respiration.

Table 5: Average total soluble solids (Brix)

\begin{tabular}{|l|l|l|l|}
\hline $\begin{array}{l}\text { CHILLING } \\
\text { PERIOD }\end{array}$ & 7 & 14 & 21 \\
\cline { 1 - 4 } VARIETY & & & \\
\hline AKOMA & $4.07 \mathrm{a}$ & $3.20 \mathrm{a}$ & $2.96 \mathrm{a}$ \\
\hline PECTOMECH & $2.00 \mathrm{~b}$ & $2.67 \mathrm{~b}$ & $3.00 \mathrm{~b}$ \\
\hline POWER & $3.56 \mathrm{c}$ & $3.12 \mathrm{c}$ & $2.96 \mathrm{a}$ \\
\hline
\end{tabular}

$\mathrm{pH}$ :

The acidity of tomato fruits subjected to chilling decreased after fruits were exposed to ambient conditions for three days (Castro, 2005). Will et al. (1981) showed, that amount of organic acid usually decrease during maturity, because they are substrate of respiration. $\mathrm{pH}$ rises to a maximum at or soon after the climacteric and then usually shows a slight fall as ripening progresses (Simmonds, 1969).

It was observed that the $\mathrm{pH}$ of the three cultivars before the experiment was three. After exposure to low temperature, it was again recorded that the $\mathrm{pH}$ was at three and increased gradually to four. The $\mathrm{pH}$ of a produce depends the genotype, the soil type for cultivation and the fertilizer application (Simmonds, 1969). For this study there were different cultivars though but they were all taken from the same field and this field received the same soil treatment and this could be the reason for the similarity in $\mathrm{pH}$. As fruits approach senescence or decay, the level of alkalinity increases thereby increasing the $\mathrm{pH}$. This accounts for the reason why the $\mathrm{pH}$ increased after some few days of exposure to ambient conditions. Also, the level of chilling injury directly affected the aging of the tomato and also the $\mathrm{pH}$.

Table 6: Average $\mathrm{pH}$ of the fruits

\begin{tabular}{|l|l|l|l|}
\hline \begin{tabular}{l|l|l|} 
CHILLING \\
PERIOD
\end{tabular} & 7 & 14 & 21 \\
\cline { 1 - 3 } VARIETY & & & \\
\hline AKOMA & $4.00 \mathrm{a}$ & $4.00 \mathrm{a}$ & $4.00 \mathrm{a}$ \\
\hline PECTOMECH & $4.00 \mathrm{a}$ & $4.00 \mathrm{a}$ & $4.00 \mathrm{a}$ \\
\hline POWER & $4.00 \mathrm{a}$ & $4.00 \mathrm{a}$ & $4.00 \mathrm{a}$ \\
\hline
\end{tabular}

Severity of Pitting and Decay : The main symptoms of chilling injury in tomato are pitting and decay, 
browning of tissues, water soaked areas and increase susceptibility to fungal infections (Morris, 1982). Pitting and decay was very visible in all cultivars after the fruits were brought to room temperature. A similar result was recorded in a research by Mohammed and Brathwaite (2000).

The severity of pitting and decay varied among the three cultivars and the durations of exposure. The severity of pitting and decay was measured with a hedonic scale. The difference in the severity of pitting and decay was not significant fourteen and twentyone days storage. There was a significant difference $(p<0.05)$ in the severity of pitting and decay of Akoma and Power, and Akoma and Pectomech. Abou-Aziz et al. (1976) reported that the effect of storage temperature on chilling induced quality changes in tomatoes varies with cultivar and hence the differences in severity of pitting and decay can be attributed to the fact that the fruits were of different genotype and cultivars.

The severity of pitting and decay was increasing with increasing duration exposure to low temperature. The effect of low temperatures on tomato varies with the duration of exposure to those temperatures as stated in the work carried out by Hobson (1981).It was also observed that as tomato stayed in the ambient conditions for longer periods, the rate of pitting and decay increased. The severity to pitting and decay for was highest on day seven for Power and Pectomech chilled for seven days. This means that during the storage of tomato under lower temperatures fruits that were keep for a long will have a higher susceptibility to chilling injury.

Table 7: Average severity to pitting and decay

\begin{tabular}{|l|l|l|l|}
\hline $\begin{array}{l}\text { CHILLING } \\
\text { PERIOD }\end{array}$ & 7 & 14 & 21 \\
\cline { 1 - 3 } VARIETY & & & \\
\hline AKOMA & $6.00 \mathrm{a}$ & $8.00 \mathrm{a}$ & $8.00 \mathrm{a}$ \\
\hline PECTOMECH & $8.00 \mathrm{~b}$ & $8.00 \mathrm{a}$ & $8.00 \mathrm{a}$ \\
\hline POWER & $8.00 \mathrm{~b}$ & $8.00 \mathrm{a}$ & $8.00 \mathrm{a}$ \\
\hline
\end{tabular}

Brown Discolouration of Skin Tissues: The colour of fruits or vegetable affects the acceptance of the produce by consumers. Tomato at fully ripe stage are either bright red or pinkish red (Cantwell, 2008) thus when more than $90 \%$ of the surface colour has turned red or pinkish red. The discolouration or browning of tissues of plant material is caused be necrosis (Pretel et al., 1995).

In the work of Mohammed and Brathwaite (2000), it was recorded that tomato fruits exposed to $10^{\circ} \mathrm{C}$ for seven days had $60 \%$ of their skin brown after three days under ambient conditions. From the results it can be seen that the rate of brown discolouration of tissues varied between cultivars. Pectomech recorded the highest and also all the three cultivars had their $90 \%$ of their tissues browned seven day after the ambient temperature storage.

After seven days of exposure to the low temperature, Akoma was the cultivar with least of its skin tissues browned whiles Pectomech had $0-10 \%$ of its skin tissues browned on day one and increase to more than $90 \%$ at day seven. The rate and variation of brown spots on the tissue of tomato varied among the three cultivars. This therefore means that the rate of browning of tissues exposed to low temperature depends on maturity stage, duration under storage temperature and the variety of plant material (Pretel et al., 1995).

Table 8: Average brown discoloration

\begin{tabular}{|l|l|l|l|}
\hline $\begin{array}{l}\text { CHILLING } \\
\text { PERIOD }\end{array}$ & 7 & 14 & 21 \\
\cline { 1 - 4 } VARIETY & & & \\
\hline AKOMA & $2 . .67 \mathrm{a}$ & $4.33 \mathrm{a}$ & $3.67 \mathrm{a}$ \\
\hline PECTOMECH & $4.67 \mathrm{~b}$ & $5.00 \mathrm{a}$ & $5.00 \mathrm{~b}$ \\
\hline POWER & $5.00 \mathrm{~b}$ & $4.67 \mathrm{a}$ & $4.67 \mathrm{~b}$ \\
\hline
\end{tabular}

Resistance to Chilling Injury:

The ability of tropical and sub-tropical species to tolerate the effect of exposing them to low temperatures shows its resistance to chilling injury. Resistance of the fruit to chilling injury was ranked for each cultivar on a scale of $1-10$ with $1=$ most susceptible and $10=$ most resistant (Cabrera and Saltveit, 1992).

There was no significant difference $(p \geq 0.05)$ in the resistance to chilling of all the cultivars stored for seven and twenty-one days. There was however, a significant difference between Akoma and Pectomech, and Akoma and Power The effect of storage temperature on chilling induced quality changes in tomatoes varies with cultivar (Abou-Aziz et al., 1976), duration of storage (Hobson, 1981) and ripeness of the fruit (Autio and Bramlage, 1986). Akoma showed the highest resistance to chilling injury after fourteen days of low temperature storage with Power and Pectomech showing the least for all the three durations.

The effect of storage temperature on chilling induced quality changes in tomatoes varies with cultivar (Abou-Aziz et al., 1976), duration of storage (Hobson, 
Agric. Biol. J. N. Am., 2011, 2(5): 799-805

1981) and ripeness of the fruit (Autio and Bramlage, 1986). The fruits were all of the same ripening stage and hence, the difference in resistance to chilling injury was due to the difference in cultivar and the storage period.

Table 9: Average resistance to chilling injury

\begin{tabular}{|l|l|l|l|}
\hline $\begin{array}{l}\text { CHILLING } \\
\text { PERIOD }\end{array}$ & 7 & 14 & 21 \\
\cline { 1 - 4 } VARIETY & & & \\
\hline AKOMA & $1.00 \mathrm{a}$ & $4.67 \mathrm{a}$ & $1.67 \mathrm{a}$ \\
\hline PECTOMECH & $1.00 \mathrm{a}$ & $1.00 \mathrm{~b}$ & $1.00 \mathrm{a}$ \\
\hline POWER & $1.00 \mathrm{a}$ & $1.00 \mathrm{~b}$ & $1.00 \mathrm{a}$ \\
\hline
\end{tabular}

\section{Overall Quality}

Quality of tomato fruit after harvest is mainly affected by genotype, environment and postharvest handling (Fuch et al., 1995). The effect of storage temperature on chilling induced quality changes in tomatoes varies with cultivar (Abou-Aziz et al., 1976), duration of storage (Hobson, 1981) and ripeness of the fruit (Autio and Bramlage, 1986). In this experiment, fruits were all taken from the same field, compared under the same duration of storage and were all at the same stage of ripeness. This therefore, means that the variation in the quality of the fruits was dependant on the cultivar and the genotype.

The overall quality of tomato fruits depends on its appearance, taste and for what purpose it could be used (Cabrera and Saltveit, 1992). The rate of decrease of quality varied with cultivar and duration of storage under low temperature. The overall quality of all three cultivars dropped as from day one till day seven. This means that as the tomato fruits stay longer under room conditions after chilling, the overall quality reduces.

It can be observed that Akoma recorded the highest level of average quality for all the three duration with Power recording the lowest average. The difference in the overall quality was not significant between fruits exposed for seven and fourteen days. The difference in the overall quality was however, significant $(p<0.05)$ between Akoma and Power, and Pectomech and Power.

Table 10: Average overall quality

\begin{tabular}{|l|l|l|l|}
\hline $\begin{array}{l}\text { CHILLING } \\
\text { PERIOD }\end{array}$ & 7 & 14 & 21 \\
\cline { 1 - 3 } VARIETY & $0.00 \mathrm{a}$ & $0.00 \mathrm{a}$ & $0.00 \mathrm{a}$ \\
\cline { 1 - 4 } AKOMA & $0.00 \mathrm{a}$ & $0.00 \mathrm{a}$ & $0.00 \mathrm{a}$ \\
\hline PECTOMECH & $0.00 \mathrm{a}$ & $0.00 \mathrm{a}$ & $0.33 \mathrm{~b}$ \\
\hline POWER & & & \\
\hline
\end{tabular}

\section{CONCLUSION}

The overall purpose of storage is to extend shelf life, increase usage period and availability of a product. This purpose cannot be achieved if the product kept in storage goes bad or cannot be sold to gain profit. In conclusion, exposing tomato fruits stored at low temperatures had their shelf life extended but their usage and market values reduced.

The exposure of all the three cultivars to low temperature was recorded to be best at seven days since the symptoms of chilling injury was lower in them compared to those kept for fourteen and twenty-one days. Also, the weight loss was minimal in those fruits that were stored for seven days and weight is one of the indicators of a good market price. The fruits kept for fourteen days under the low temperature had their weight loss higher those that were kept for seven days. When the fruits were brought to ambient conditions, the symptoms of chilling injury manifested more quickly in Power and Pectoemch, thereby reducing the number of days the fruits spent under ambient condition storage. Akoma showed signs of chilling injury gradually and the fruits maintained their quality under ambient condition till the fourth day. Power and Pectomech stayed quality for only the first two days with very high weight losses.

The fruits kept under low temperature for twenty-one stored longest. They however, lose their quality within a few days when brought to ambient conditions storage. The symptoms of chilling injury were highest in the fruits that were stored under the low temperature for twenty-one days. Pectomech became very susceptible to chilling injury at the end of day two and could no longer be stored under room temperature. Power recorded similar results as Pectomech but the rate of browning of tissues was higher for Pectomech. Akoma stayed under ambient conditions after twenty-one days of low temperature storage for four days before losing its quality totally.

The storage, therefore, of tomato fruits at $10^{\circ} \mathrm{C}$ was best if fruits are stored for seven days. Pectomech and Power stored for fourteen and twenty one but the number of days they spent under ambient conditions remaining quality was lesser compared to Akoma. Akoma stored for fourteen days and twenty one days under the low temperature stayed longer under ambient conditions storage compared to Power and Pectomech store under the low conditions for the same period. 


\section{REFERENCES}

Abou-Aziz, A. B., El-Nataway, S. M., Adel-Wahab, F. K., Kader, A. A. (1976). The effect of storage temperature on quality and decay percentage of 'Pairi' and 'Taimour' mango fruit. J. Amer. Soc. Hort. Sci., 117(5) 5: 65-72.

Adegoroye, A. S., Jolliffe, P. A., Tung, M. A. (1989). Texture characteristics of tomato fruits (Lycopersicon esculentum) affected by sunscald. J. Sc. Food Agr., 49: 95-102.

Asare-Bediako, E., Showemimo, F. A., Buah, J. N, Ushawu, Y., (2007). Tomato production constrain at Bolgatanga. Journal of applied science 7 (3): 459-461.

Auito, W. R., Bramlage, W. J. (1986). Chilling sensitivity of tomato fruits in relation to ripening and senescence. $J$. Amer. Soc. Hort. Sci. 111(2): 201-205.

Beecher, R. (2000). Postharvest handling of fruits and vegetables. New Delhi: ATTRA Publication. Pg. 116.

Cabrera, R. M. and Saltveit, M. E Jr., (1992). Cucumber cultivars differ in their response to chilling temperatures. J. Amer. Soc. Hort. Sci., 117(5): 802807.

Cantwell, M., and Suslow, T., (2009). Recommendations for Maintaining Postharvest Quality. California: University of California, Davis, CA 95616.

F. A. O (2005). Statistics Book and National Crop Production. Food and Agriculture Organization, Rome. ftp://ftp.fao.org/docrep/fao/009/j8672e/j8672e00.pdf (accessed: 05-01-2009)

Franzio, S. (1996). Social Psychology. London: Oxford Press. Pg. 305.
Fuchs, M., Provvidenti, R., Slightom, J. L., and Gonsalves, D., (1995). Evaluation of transgenic tomato plants expressing the coat protein gene of cucumber mosaic virus, WL under field conditions. J. Plant Disease 80 (4): $270-275$.

Hobson, G. E. (1981). The short-term storage of tomato fruit. J. Hortic. Sci., 56: 363-368.

Kitinoja, L. and Hussein, A. (2005). Postharvest Tools and Supplies Kit Utilization, Calibration and Maintenance Manual. California: University Of California, Davis. Pg. 2, 11, 14.

Levitt, J. (1980). Chilling Injury and Resistance in Response of Plants to Environmental Stress. New York: Academic Press. Pg. 46

Mohammed, M. and Brathwaite, R. I. A (2000) Ripening effects on the chilling sensitivity of processing and non-processing tomato cultivars. J. Appl. Hort., 2(2):76-78

Peralta, E. and Spooner, D. M., (2001). Granule-bound starch synthesis (GBSSI) gene phylogeny of wild tomatoes (Solanum L.section Lycopersicon Mill.Wettst. subsection Lycopersicon). Amer. Journal of Botany, 88 (10): 1888-1902

Pretel, H. E and Hudson, S. R (1995). Tropical Crops Dicotyledons: London: Longman Publishers. Pg. 199237.

Simmonds, N. W. (1969). Bananas. $2^{\text {nd }}$ Edition. London: Longman Publ. Pg. 64.

Skow, L. J (1998) Chilling injury of horticultural crops. Ontario: Horticultural Research Institute. Pg. 736-202

Žnidarčič, D., Požrl, T. (2006). Comparative study of quality changes in tomato. Acta agriculturae Slovenica, 87 (2): 242-243. 